\title{
Rodzaj zatrudnienia a dobrostan psychiczny i zaangażowanie pracowników - na podstawie przeglądu literatury
}

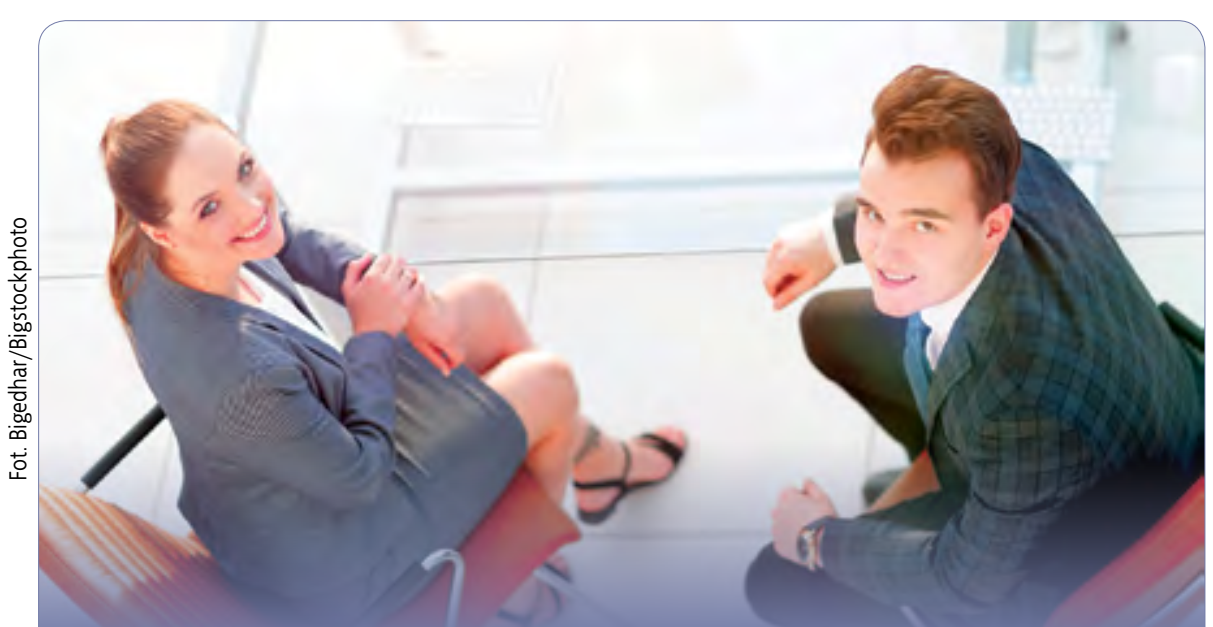

W artykule zaprezentowano przegląd literatury dotyczącej badań nad związkiem pomiędzy rodzajem zatrudnienia a dobrostanem psychicznym i zaangażowaniem pracowników, które zrealizowano w wielu krajach europejskich i pozaeuropejskich w ostatnich dekadach. Te wyniki nie są jednoznaczne. Niektóre z nich wskazują na to, że to pracownicy zatrudnieni na podstawie umów na czas nieokreślony mają lepsze samopoczucie psychiczne i są bardziej wydajni w pracy niż pracownicy zatrudnieni czasowo, inne zaś pokazują odwrotne zależności. Jedną z przyczyn tych rozbieżności może być różny kontekst społeczno-gospodarczym krajów, w których przeprowadzano te badania. Z punktu widzenia zarówno sukcesu ekonomicznego, jak i zachowania zdrowia pracowników, wskazane byłoby przeprowadzenie podobnych badań także w Polsce. Na tle zwiększającego się prawdopodobieństwa zanikania zatrudnienia stałego na rynku pracy w świecie jesteśmy bowiem krajem, który ze względu na najwyższe wskaźniki zatrudnienia czasowego może doświadczać tego procesu szybciej niż inne kraje. Stowa kluczowe: umowa o pracę, rodzaj zatrudnienia, produktywność, dobrostan, zaangażowanie

The type of employment and the mental well-being and involvement of employees - based on a literature review

The article presents a review of the literature on research on the relationship between the type of employment contract and the well-being and productivity of employees, carried out in many European and non-European countries in recent decades. These results are inconclusive. Some of them indicate that employees employed under permanent contracts have a better mental well-being and are more productive at work than temporary employees, while others show the opposite relationship. One of the reasons for these discrepancies may be the different socio-economic context of the countries in which the research was carried out. In the context of the increasing probability of disappearance of permanent employment on the labour market in the world in general, we are a country which, due to the highest rates of temporary employment, can experience this process faster than other countries.

Keywords: job contract, form of employment, productivity, well-being, engagement

\section{Wstęp}

W ostatnich dziesięcioleciach, a zwłaszcza na przestrzeni ostatnich 20-30 lat, rynek pracy ewoluował w kierunku niestandardowych form pracy (oraz niestandardowych form zatrudnienia), takich jak praca zależna (ang. contingent), alternatywna (ang. alternative), atypowa (ang. atypical) czy niestała (ang. non-permanent) [1-4]. Liczba osób wykonujących taką pracę rośnie ze względu na procesy globalizacji, wzrost poziomu konkurencji oraz dynamiczny rozwój technologiczny (w tym digitalizację), które wymuszają wdrażanie innowacji i ciągłą restrukturyzację przedsiębiorstw, a przez to także konieczność położenia większego nacisku na kontrolę kosztów pracy i elastyczność organizacji [5-7].

Wraz z niestandardowymi formami pracy upowszechniają się także niestandardowe formy zatrudnienia. Mimo braku jednolitego nazewnictwa i definicji zatrudnienia niestandardowego uważa się, że różni się ono od standardowego pod trzema względami:

- zatrudnienie standardowe charakteryzuje stałość i możliwość kontynuacji

- zatrudnienie standardowe pozwala (na ogół) na prace w miejscu pracy zorganizowanym przez pracodawcę, na jego warunkach i pod jego superwizją

- zatrudnienie standardowe w większości krajów jest związane z licznymi uprawnieniami - takimi jak: płaca minimalna, ubezpieczenie od bezrobocia, ochrona przed nieuzasadnionym zwolnieniem z pracy, płatny urlop - które niekoniecznie obowiązują w przypadku zatrudnienia niestandardowego [3].

Ze względu na szerokie definiowanie pojęcia zatrudnienia niestandardowego istnieją także różne jego klasyfikacje. Według klasyfikacji ILO zatrudnienie niestandardowe może przyjmować jedną z czterech różnych form, takich jak:

- zatrudnienie tymczasowe (np. zatrudnienie na określony czas, zatrudnienie do projektu, praca sezonowa)

- praca w niepełnym wymiarze godzin (praca na pół/część etatu, praca na zero etatu, praca na wezwanie) 


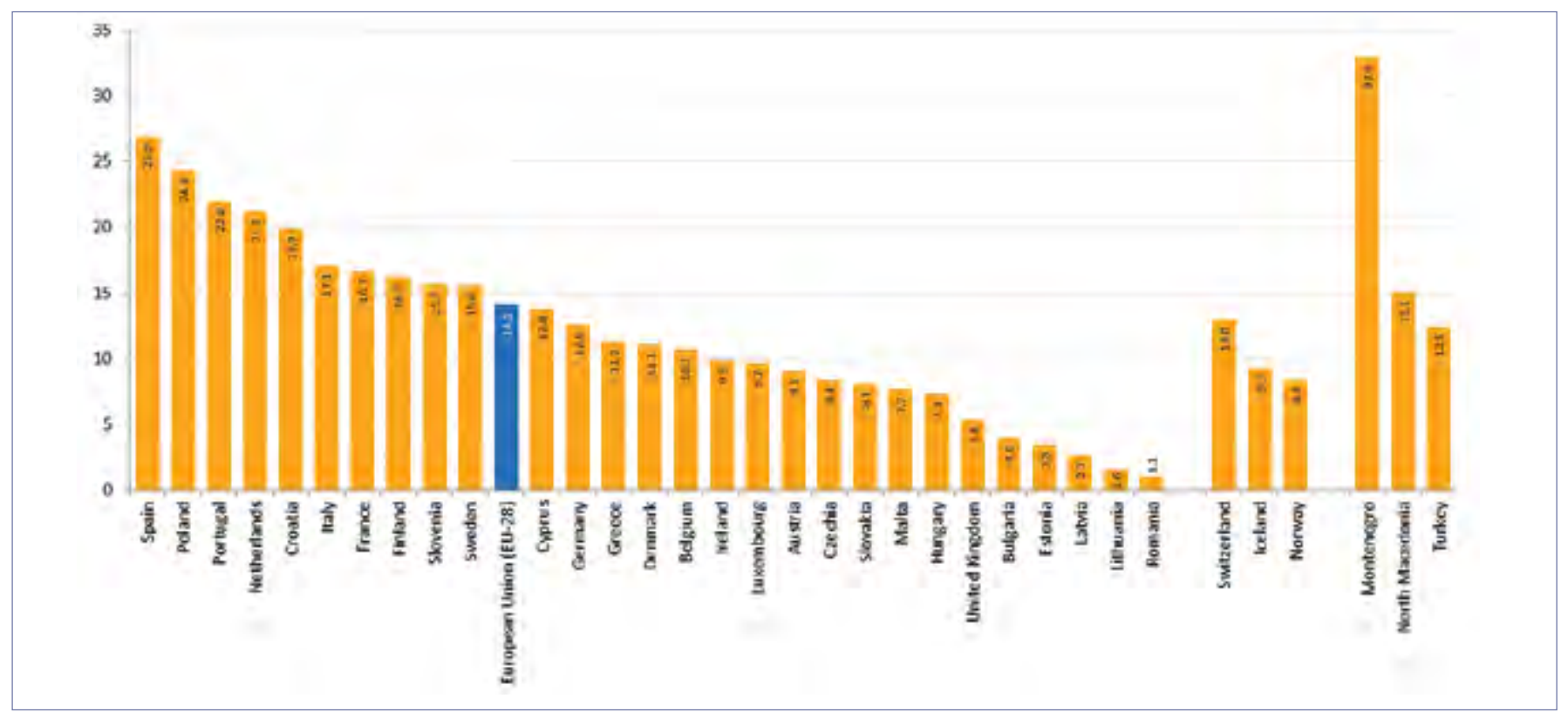

Rys. Pracownicy tymczasowi (\%) jako część ogółu pracowników w grupie wiekowej 15-64 w 2018 r. [10]

Fig. Temporary workers (\%) as part of the total number of employees in the 15-64 age group in 2018 [10]

- wielostronne stosunki pracy (zatrudnienie niebezpośrednie, przez podwykonawców lub agencje pracy tymczasowej)

- ukryte stosunki pracy i samozatrudnienie zależne [4].

Zgodnie z ujęciem polskich badaczy różne formy zatrudnienia niestandardowego mogą być generalnie podzielone na trzy główne grupy:

- zatrudnienie pracownicze, które obejmuje umowy terminowe (na czas określony) oraz pracę w niepełnym wymiarze godzin

- zatrudnienie niepracownicze, które dotyczy osób zatrudnionych na podstawie umowy cywilnoprawnej oraz osób samozatrudnionych

- zatrudnienie mieszane, obejmujące pracę tymczasową, telepracę oraz pracę nakładczą [8]. Do niedawna w Polsce największą grupę wśród osób zatrudnionych niestandardowo stanowili pracownicy posiadający umowy o pracę na czas określony. Znacznie rzadziej odnotowywano w naszym kraju bardziej popularne w Europie formy zatrudnienia niestandardo wego, takie jak: praca w niepełnym wymiarze godzin, leasing pracowniczy, wypożyczanie pracowników, praca na wezwanie i na telefon, job-sharing czy nawet telepraca. Obecnie coraz bardziej popularne stają się takie rodzaje zatrudnienia niepracowniczego, jak umowy zlecenia, umowy o dzieło, umowy agencyjne czy samozatrudnienie, $w$ tym wiele form $w$ ramach tzw. pracy platformowej lub freelancingu [9]. Po wybuchu pandemii COVID-19 najbardziej popularną niestandardową formą pracy (ze względu na miejsce jej wykonywania) stała się oczywiście praca zdalna.

Masowy wzrost zatrudnienia niestandardowego, w którym dominowało zatrudnienie na podstawie umów na czas określony, nastą pił w Polsce w pierwszej połowie XX w. O ile w 1999 r. osoby na takich umowach stanowiły zaledwie 4,6\% ogółu pracujących, to w $2007 \mathrm{r}$. ich odsetek wzrósł do 28,2\%. W latach 2010-2016 w Polsce odnotowywano najwyższy w Europie wskaźnik zatrudnienia pracowników na umowy na czas określony. W 2018 r. wyprzedziły nas pod tym względem Czarnogóra i Hiszpania, jednak wciąż znajdowaliśmy się w czołówce ze wskaźnikiem na poziomie 24,3\% wszystkich zatrudnionych, podczas gdy wskaźnik europejski szacowano na $14,1 \%$, a w krajach OECD był jeszcze niższy (11\%) [10], (por. rys).

Wspomniany spadek nastąpił, gdy w $2016 \mathrm{r}$., po wielkiej debacie społecznej na temat negatywnych konsekwencji zatrudnienia na czas określony, dokonano zmiany prawa. Zgodnie ze znowelizowanymi przepisami pracodawca może zawrzeć z pracownikiem maksymalnie trzy umowy na czas określony, przy czym łączna długość ich trwania nie może przekroczyć 33 miesięcy. Czwarta umowa z tym samym pracodawcą powinna być umową na czas nieokreślony, którą można rozwiązać z zachowaniem trzymiesięcznego okresu wypowiedzenia, jeśli pracownik jest zatrudniony w firmie minimum trzy lata. Ocenia się, że od wprowadzenia tej zasady zatrudnienie na czas określony ma w Polsce mniej prekaryjną formę, jednak pracodawca nadal może je zakończyć bez podania powodów. Ponadto taka forma zatrudnienia zazwyczaj nie wynika z preferencji pracownika - prawie $70 \%$ osób zatrudnionych czasowo deklarowało, że nie mogło znaleźć tzw. stałego zatrudnienia. Niski jest także wskaźnik przejść $z$ umów terminowych na umowy stałe - zaledwie ok. 1/3 po trzech latach przekształca się w umowy na czas nieokreślony. Prawdopodobieństwo przejścia na umowę bezterminową zależy głównie od wieku i wykształcenia pracownika, przy czym największe szanse mają osoby z wykształceniem wyższym z tzw. grupy prime-age (czyli grupy osób młodych w wieku najwyższej aktywności zawodowej), natomiast najmniejsze - osoby z wykształceniem gimnazjalnym lub niższym (bez względu na wiek) [11].

Panuje przekonanie, że pracownicy zatrudnieni na umowach terminowych mniej intensywnie wykorzystują swoje umiejętności i rzadziej uczestniczą w szkoleniach organizowanych przez pracodawcę. Takie osoby mają więc mniej okazji nie tylko do tego, by spożytkować posiadane kompetencje, lecz także - by je podnosić. Tymczasem mniejsza akumulacja indywidualnego kapitału ludzkiego może w przyszłości prowadzić do ograniczenia możliwości znalezienia pracy ze stałą umową. Wiadomo także, że osoby zatrudnione na podstawie umów terminowych zarabiają mniej i ta różnica utrzymuje się w czasie [12].

Jak już wspomniano, z powodu pandemii COVID-19 najbardziej popularną formą pracy niestandardowej staje się - zarówno w Polsce, jak i na świecie - praca zdalna. Istnieje już sporo doniesień na temat wpływu tej formy pracy na sytuację zawodową i zdrowotną osób pracujących w taki sposób. Warto jednak pamiętać, że na te zależności ogromny wpływ ma sama pandemia, w tym lęk przed zakażeniem czy trudności w godzeniu życia rodzinnego z zawodowym, co wynika z kompletnego nieprzygotowania pracowników do tej formy pracy. W tym sensie praca zdalna stanowi specyficzną formę pracy niestandardowej, która dodatkowo może się zmieniać wraz ze zmianami sytuacji epidemicznej i społecznej. Zanim powstaną pogłębione opracowania na ten temat, warto się przyjrzeć danym dostępnym w literaturze, dotyczącym dominujących do niedawna form zatrudnienia niestandardowego na przykładzie osób zatrudnionych na umowy na czas 
określony, nazywanych przez anglosaskich badaczy temporary workers.

Celem artykułu jest prezentacja danych literaturowych na temat związku zatrudnienia na czas określony z dobrostanem i produk tywnością pracowników oraz ich porównanie z danymi dotyczącymi osób zatrudnionych na podstawie umów stałych. Jest to ważne w kontekście rosnącego prawdopodobieństwa zanikania zatrudnienia standardowego/stałego w przyszłości.

\section{Rodzaj zatrudnienia a dobrostan psychiczny}

Zwiększająca się skala zatrudnienia czasowego na świecie i w Europie oraz prekaryjność przypisywana tej formie zatrudnienia wzbudziły wśród wielu badaczy chęć sprawdzenia, czy owo zatrudnienie jest także związane z gorszym dobrostanem pracowników.

Mimo że pierwsza metaanaliza danych na temat związku pomiędzy zatrudnieniem czaso wym i dobrostanem, dokonana przez Virtanen i zespół w 2005 r., wskazywała na większe pro blemy psychologiczne wśród pracowników czasowych niż stałych, to jednak te różnice nie były duże [13]. Przykładowo Benavides i inni analizowali dane $z$ drugiego sondażu europejskiego na temat warunków pracy (ang. the Second European Survey of Working Conditions), po chodzące od 15146 zatrudnionych z 15 krajów europejskich [14]. Badacze sprawdzali, czy zatrudnienie prekaryjne - rozumiane jako zatrudnienie na czas określony w pełnym lub niepełnym wymiarze czasu pracy - jest związane z niższymi wskaźnikami zadowolenia z pracy, absencji chorobowej i stresu oraz z wyższymi wskaźnikami problemów zdrowotnych (w po równaniu ze wskaźnikami charakteryzującymi zatrudnienie stałe). Analizy potwierdziły, że eu ropejscy pracownicy zatrudnieni czasowo byli - w porównaniu z pracownikami zatrudnionymi na stałe - bardziej niezadowoleni ze swojej pracy, a jednocześnie rzadziej nie stawiali się w pracy z powodu choroby i byli mniej zestresowani. Podobnie niejednoznaczne wyniki uzyskali Virtanen i inni [15], którzy badali pracowników dziesięciu fińskich szpitali. Celem badania rów nież było porównanie statusu zdrowotnego pracowników zatrudnionych na czas określony i stałych. Wyniki ujawniły, że pierwsza grupa osób miała lepszą samoocenę stanu zdrowia niż pracownicy stali, choć między grupami nie było różnic w częstości występowania zdiagno zowanych chorób przewlekłych i problemów psychiatrycznych. W innym badaniu [16] spraw dzano różnice w stanie zdrowia 15468 osób zatrudnionych na stałe i zatrudnionych w innych atypowych formach pracy, w tym pracowników zatrudnionych na czas określony, osób bezro botnych i poszukujących pracy. Jak się okazało, pracownicy zatrudnieni na czas określony mieli tyle samo lub nawet mniej problemów zdrowotnych (związanych ze zdrowiem i z depresją) niż pracownicy stali [16]

Hesselink i van Vuuren [17] porównywali m.in. subiektywnie oceniane zdrowie w różnych grupach holenderskich pracowników (zatrudnionych w pełnym wymiarze czasu, na część etatu, na czas określony lub przez agencję pracy tymczasowej oraz samozatrudnionych). Stwierdzili, że osoby prowadzące działalność na własny rachunek zgłaszały najmniejszą liczbę dolegliwości zdrowotnych, nieco więcej - pracownicy zatrudnieni w pełnym wymiarze godzin ze stałymi umowami, a pozostałe trzy grupy (pracownicy pracujący w niepełnym wymiarze godzin, pracownicy tymczasowi i pracownicy agencyjni) uzyskały najwyższe wyniki w zakresie skarg na dolegliwości zdrowotne. Niejednoznaczne wnioski na temat zdrowia pracowników zatrudnionych na umowy czasowe pochodzą także z innych badań [13]

Późniejsze badania, zwłaszcza badania podłużne, na ogół potwierdzały związek pomię dzy zatrudnieniem na czas określony a gorszym zdrowiem psychicznym w populacjach europejskich i pozaeuropejskich. I tak, w badaniu pochodzącym z Finlandii, przeprowadzonym na dużej próbie pracowników fińskich z sektora publicznego, ujawniono, że epizody niezdolności do pracy z powodu depresji były dłuższe wśród pracowników zatrudnionych na czas określony niż wśród pracowników stałych i tym samym dłuższe były powroty do pracy tych osób, zwłaszcza starszych i gorzej wykształconych [16]. Z kolei Julià i współpracownicy [18], którzy w 2013 r. badali 5679 hiszpańskich pracowników zatrudnionych albo czasowo, albo na czas nieokreślony, stwierdzili, że osoby mające krótkoterminowe umowy o pracę są narażone na depresję $w$ większym stopniu niż osoby z umowami długoterminowymi. Badacze stwierdzili też, że im niższy był poziom stabilności zatrudnienia, tym gorsze było zdrowie psychiczne pracowników.

Związek pomiędzy zatrudnieniem czasowym a dobrostanem pracowników potwierdzono także w kilku badaniach wykonanych w Korei Południowej. W 2008 r. Kim i zespół [19] doszli do wniosku, że pracownicy pozostający w zatrudnieniu określonym przez autorów jako prekaryjne (pracownicy zatrudnieni na podstawie umów na czas określony lub wręcz odnawianych codziennie, zatrudnieni na część pełnego wymiaru czasu pracy lub na krótkoterminowe zastępstwo) charakteryzowali się gorszym zdrowiem niż pracownicy zatrudnieni na stałe. Późniejsze badanie, przeprowadzone w 2017 r. przez Han i współpracowników [20] w grupie 24173 koreańskich pracowników pokazało, że zatrudnienie prekaryjne było silnie związane z nastrojem depresyjnym, w tym z myślami samobójczymi, ale dotyczyło to tylko pracowników płci męskiej i pracowników o niskim lub średnim poziomie dochodów. Kategoria precarious work obejmowała w tym badaniu szeroką grupę osób - pracowników zatrudnionych czasowo (temporary workers), czyli na tzw. dniówkę/godziny (daily employed workers), pracujących w niepełnym wymiarze czasu pracy (part-time workers), oddelegowanych (dispatched workers), podwykonawców (subcontracted workers) i innych.

Z kolei Quesnel-Vallée i zespół [21] w 2010 r. analizowali dane pochodzące $z$ amerykańskiego badania podłużnego młodzieży (National Longitudinal Survey of Youth) i stwierdzili, że bycie pracownikiem zatrudnionym czasowo zwiększa ryzyko zaburzeń depresyjnych w późniejszym okresie. Ten wynik dotyczy jednak tylko zatrudnionych przez agencje pracy i podwykonawców. Kilka innych danych dowodzi, że praca czasowa jest bardziej szkodliwa dla zdrowia psychicznego mężczyzn [22] lub jedynie osób o niskim poziomie wykształcenia [23].

Istnieje jednak grupa badań, które jednoznacznie wskazuja, że stan zdrowia (również psychicznego) pracowników stałych jest gorszy w porównaniu z pracownikami zatrudnionymi czasowo. Jako przykład niech posłuży doniesienie Guest, Isakssona i de Witte'a [24] z 2010 r., którzy zbadali ponad 5000 stałych oraz
Wybuch pandemii COVID-19 spowodował wzrost popularności pracy zdalnej w Polsce i na świecie The outbreak of the COVID-19 pandemic increased the popularity of remote work in Poland and in the world 
tymczasowych pracowników ze Szwecji, z Niemiec,Holandii, Belgii, Wielkiej Brytanii, Hiszpanii i Izraela. Większość tych pracowników posiadała kontrakty zawarte na czas określony i była zatrudniona przez agencje pracy, resztę zaś stanowili pracownicy sezonowi. Przeciwnie niż zakładano, okazało się, że to pracownicy stali, a nie czasowi, mieli gorsze samopoczu cie, tj. wykazywali wyższy poziom irytacji, lęku i depresji oraz niższy poziom satysfakcji z pracy i zdrowia ogólnego. Goudswaard i Andries [25] w 2002 r. analizowali wyniki dotyczące samopoczucia i warunków pracy pracowników zatrudnionych przez agencje pracy znajdujące się w Danii, Finlandii, we Francji, w Niemczech, Holandii, Hiszpanii i Szwecji. Autorzy tych badań stwierdzili, że osoby te odczuwają niższy poziom stresu i mniej dolegliwości mięśniowo -szkieletowych w porównaniu z pracownikami stałymi.

\section{Rodzaj zatrudnienia \\ a zaangażowanie $\mathbf{w}$ pracę}

W wielu badaniach próbowano ustalić, czy pracownicy zatrudnieni na czas określony różnią się od pracowników stałych pod wzglę dem produktywności i zaangażowania w pracę Podobnie jak w przypadku badania zależności pomiędzy rodzajem kontraktu a dobrostanem również tu wyniki nie są jednoznaczne. Część danych wskazuje, że osoby na kontraktach krótkoterminowych mniej angażują się w pracę niż osoby na kontraktach bezterminowych [26] Są jednak badania, które nie potwierdzają ne gatywnego związku pomiędzy pracą czaso wą a zaangażowaniem w pracę i - co więcej - wskazują na coś przeciwnego: że mniej zaan gażowane są osoby zatrudnione na stałe [27].

Przykład holenderski przekonuje, że osoby zatrudnione przez agencje pracy wykazują znacznie mniejsze zaangażowanie w porównaniu z osobami zatrudnionymi na podstawie umowy stałej lub czasowej [27]. Podobne wnioski płyną z przeprowadzonych w 2006 r. badań Chambel i Castanheiry [28], które przyglądały się portugalskim pracownikom zatrudnionym na różnych rodzajach umów i ustaliły, że jedynie pracownicy na umowach stałych i czasowych angażują się w sprawy organizacji, natomiast pracownicy zatrudniani przez agencje pracy nie wykazują takich postaw. Podkreśla się tutaj podwójne (i odmienne) zaangażowanie pracowników zatrudnianych przez agencje pracy: zaangażowanie wobec agencji oraz wobec pracodawcy. O ile zaangażowanie wobec pracodawcy jest stałe, to zaangażowanie wobec agencji zależy od liczby znalezionych przez nią ofert pracy i czasu współpracy.

Badania Coyle-Shapiro i Kesslera [29] z 2002 r. oraz przeprowadzone rok później badanie de Gildera [26] dowiodły, że pracownicy na kontraktach stałych wykazują więcej zachowań obywatelskich niż osoby zatrudnione na konraktach czasowych. Guest, Isaksson i de Witte

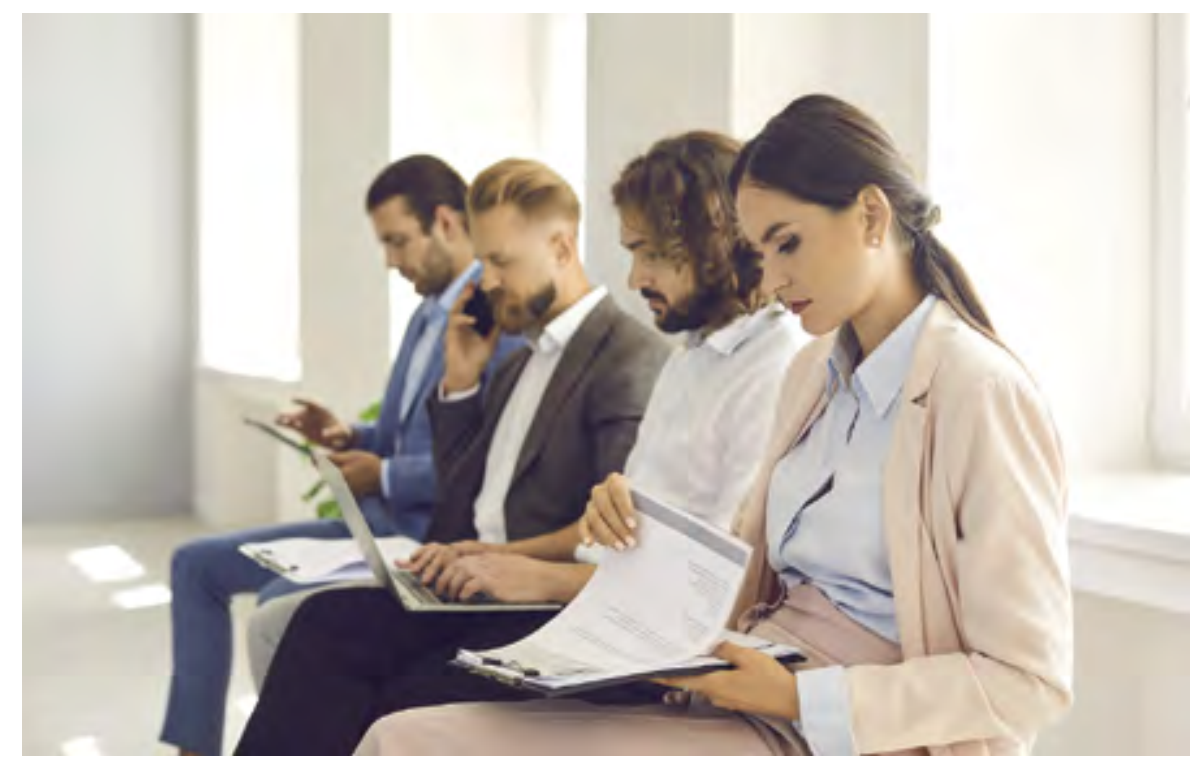

Niektóre badania holenderskie i portugalskie wskazują, że osoby zatrudnione przez agencje pracy wykazują znacznie mniejsze zaangażowanie w wykonywanie zadań zawodowych

Some Dutch and Portuguese studies show that persons employed by employment agencies show much less commitment to performing professional tasks

[24] siedem lat później stwierdzili, że pracownicy stali nie różnią się od zatrudnionych czasowo pod względem zaangażowania w pracę, co przyznali także kierownicy działów HR, którzy byli jednakowo zadowoleni z pracy obu grup osób.

Również w odniesieniu do innego wskaźnika postaw wobec pracy, jakim jest produktywność pracowników tymczasowych, wyniki badań nie są spójne. W 2005 r. Engellandt i Riphahn [30] po badaniach dotyczących szwajcarskich pracowników uznali, że osoby zatrudnione na kontraktach czasowych wkładają w pracę więcej wysiłku niż pracownicy stali. Autorzy ocenili, że ci pierwsi są w stanie poświęcić ok $60 \%$ więcej czasu na niepłatne nadgodziny, jednak dotyczy to tylko tych pracowników tymczasowych, którzy mają szansę na awans. Nie zaobserwowano natomiast efektu niższej absencji chorobowej wśród pracowników na kontraktach czasowych, co w Szwajcarii jest często uważane za sposób sygnalizowania pracodawcy swojego niezadowolenia.

Meyer i Wallette [31] po przeanalizowaniu próby 360 tys. pracowników z badania Swedish Labour Force Surveys (LFS) ujawnili, że choć absencja chorobowa szwedzkich pracowników na umowach czasowych jest niższa (w porównaniu z pracownikami stałymi), to są oni mniej skłonni do pracy po godzinach. Sverke i in. [32] stwierdzili natomiast, że to niepewność pracy, typowa dla pracowników tymczasowych, prowadzi do spadku zaangażowania, braku zaufania do organizacji, oporu przed zmianą organizacyjną oraz zmniejszonej produktywności. Uważa się, że pracownicy tymczasowi są mniej produktywni, bo zawsze są "nowi” i za każdym razem muszą się uczyć zarówno danej pracy, jak i organizacji.

\section{Podsumowanie}

Zainteresowanie badaczy i ekspertów problematyką wpływu niestandardowych form zatrudnienia na samopoczucie psychiczne i wydajność pracowników wynika z faktu, że skala tego zjawiska wciąż wzrasta na globalnym rynku pracy. Prawdopodobnie w najbliższej przyszłości zatrudnienie określane jako standardowe, w tym zwłaszcza zatrudnienie na umowę bezterminową, będzie stopniowo zanikać. W Polsce ten problem wydaje się szczególnie istotny, ponieważ nasz kraj ma jeden z najwyższych wskaźników zatrudnienia czasowego.

Przedstawione w artykule badania, przeprowadzone w ostatnich dekadach w wielu krajach europejskich i pozaeuropejskich, dotyczące związków pomiędzy rodzajem umowy o pracę a dobrostanem i produktywnością pracowników, nie dostarczyły jednoznacznych wyników. Część z nich wskazuje, że pracownicy zatrudnieni na podstawie umów na czas nieokreślony charakteryzują się lepszym samopoczuciem psychicznym i wyższą wydajnością pracy niż osoby zatrudnione czasowo, a inne dowodzą czegoś przeciwnego - że to właśnie pracownicy czasowi są bardziej zmotywowani i wydajni w pracy, a poziom ich zadowolenia z pracy dorównuje, a czasami przekracza ten, jakim charakteryzują się pracownicy zatrudnieni bezterminowo. Niespójność otrzymanych wyników może być spowodowana faktem, że w różnych badaniach brały udział odmienne grupy temporary workers, czyli osób zatrudnionych na umowy o pracę na czas określony. Raz były to osoby pracujące w niepełnym wymiarze godzin, a innym razem osoby pracujące na podstawie umów krótkoterminowych czy pracownicy zatrudniani przez agencje pracy. Ponadto zaprezentowane dane pochodzą 
z krajów o bardzo różnym kontekście społeczno-legislacyjnym i gospodarczym. Przykładowo, w niektórych krajach zatrudnienie na czas nieokreślony, dominujące w sektorze publicznym, jest często gorszej jakości w porównaniu z zatrudnieniem w sektorze prywatnym. Chociażby w Wielkiej Brytanii pracownicy zatrudnieni na umowach terminowych w tym sektorze są znacząco lepiej opłacani, co bardziej motywuje ich do pracy, rodzi mniej frustracji oraz pozwala im pozostawać w lepszej kondycji fizycznej i psychicznej [24].

Dostrzeżenie tych różnic skłoniło autorów badań do sformułowania ważnego wniosku a mianowicie, że istotną przyczyną rozbieżności wyników może być odmienny kontekst społecz no-gospodarczy krajów, w których przeprowadzano badania. $Z$ tego punktu widzenia istotne jest, aby również w Polsce analizować te zależności, zamiast opierać się wyłącznie na intuicyjnych przekonaniach o przewadze jednego lub drugiego rodzaju zatrudnienia (stałego vs. czasowego) w odniesieniu do zachowania zdrowia i wydajności pracowników czy też powoływać się jedynie na dane pochodzące $z$ innych kra jów. Jednocześnie wyniki najnowszych polskich badań wskazują na to, że osoby zatrudnione w naszym kraju na podstawie innych umów niż umowy bezterminowe charakteryzują się istotnie wyższym poziomem zaburzeń depresyjnych [33]

\section{BIBLIOGRAFIA}

[1] CONNELLY, C.E., GALLAGHER, D.G. Emerging trends in contingent work research. Journal of $\mathrm{Ma}$ nagement. 2004, 30: 959-983.

[2] VACAS-SORIANO, C. Recent developments in temporary employment: Employment growth, wages and transitions. Luxembourg: Publications Office of the European Union, Eurofound 2015.

[3] KALLEBERG, A.L Good Jobs, Bad Jobs. The Rise of Polarized and Precarious Employment Systems in the United States, 1970s-2000s. New York: Russell Sage Foundation, 2011.

[4] ILO. Non-standard employment around the world: Understanding challenges, shaping prospects 2016.

[5] ZEYTINOGLU, I., MUTESHI, J.K. Gender, race and class dimensions of nonstandard work. Industrial Relations. 2000, 55(1): 133-167.

[6] OECD. Employment Outlook The Future of Work. OECD Paris 2018, doi: 10.1787/9789264306943-en

[7] KATZ, L.F., KRUEGER, A.B. The Rise and Nature of Alternative Work Arrangements in the United States, 1995-2015. Working Paper \#603, Princeton University Industrial Relations Section, September, 2016.

[8] BĄK, E. Nietypowe formy zatrudnienia na rynku pracy. Warszawa: C.H. Beck, 2009.

[9] MANDL, I., BILETTA, I. Overview of new forms of employment - 2018 update. Luxembourg: Eurofound, 2018.
[10] STORRIE, D. Non-standard forms of employment: Recent trends and future prospects. Dublin: Eurofound, 2018.

[11] PAŃKÓW, M. Polityka państwa wobec upowszechnienia elastycznych form zatrudnienia w Polsce. Studia z Polityki Publicznej. 2015, 3(7): 140-158.

[12] KIERSZTYN, A. Analiza ekonomicznych konsekwencji zatrudnienia na czas określony dlajednostek i gospodarstw domowych. [w:]. J. Frieske, Zatrudnienie na czas określony w polskiej gospodarce. Społeczne i ekonomiczne konsekwencje zjawiska. Warszawa: IPiSS, 2012.

[13] VIRTANEN, M., et al. Temporary employment and health: A review. International Journal of Epidemiology. 2005, 34: 610-622.

[14] BENAVIDES, F.G., et al. How do types of employment relate to health indicators? Findings from the second European survey on working conditions. Journal of Epidemiology and Community Health. 2000, 54(7): 494-501, doi: 10.1136/jech.54.7.494.

[15] VIRTANEN, M., et al. Contingent employment, health and sickness absence. Scandinavian Journal of Work, Environment \& Health. 2001, 27(6): 365-372, http://www.jstor.org/stable/40967151.

[16] ERVASTI, J., et al. Is temporary employment a risk factor for work disability due to depressive disorders and delayed return to work? The Finnish Public Sector Study. Scandinavian Journal of Work, Environment \& Health. 2014, 40(4): 343-52, doi: 10.5271/sjweh.3424.

[17] HESSELINK, D.J., van VUUREN, T. Job flexibility and job insecurity: the Dutch case. European Journal of Work and Organizational Psychology. 1999, 8(2): 273-293.

[18] JULIÀ, M., et al. Precarious Employment and Quality of Employment in Relation to Health and Well-being in Europe. International Journal of Health Services. 2017, 47(3): 389-409, doi: 10.1177/0020731417707491.

[19] KIM, W., et al. Effect of working hours and precarious employment on depressive symptoms in South Korean employees: A longitudinal study. Occupational and Environmental Medicine (OEM). 2016, 73(12): 816-822.

[20] HAN, K.-M., et al. Precarious employment as sociated with depressive symptoms and suicidal ideation in adult wage workers. Journal of Affective Disorders. 2017, 218: 201-209, doi: 10.1016/j. jad.2017.04.049.

[21] QUESNEL-VALLÉE, A., DeHANEY, S., CIAMPI, A. Temporary work and depressive symptoms: A propensity score analysis. Social Science \& Medicine. 2010, 70(12): 1982-1987, doi: 10.1016/ j.socscimed.2010.02.008.

[22] KACHI, Y., OTSUKA, T., KAWADA, T. Precarious employment and the risk of serious psychological distress: a population-based cohort study in Japan. Scandinavian Journal of Work, Environment \& Health. 2014, 40: 465-472.

[23] ARTAZCOZ, L, et al. Social inequalities in the impact of flexible employment on different domains of psychosocial health. Journal of Epidemiological Community Health. 2005, 59: 761-767.

[24] GUEST, D., ISAKSSON, K., de WITTE H. Employment contracts, psychological contracts and employee well-being: An international study. Oxford: Oxford University Press, 2010

[25] GOUDSWAARD, A., ANDRIES, F. Employment status and working conditions. Luxembourg: European Foundation for the Improvement of Working and Living Conditions, Office for Official Publications of The European Community, 2002.

[26] de GILDER, D. Commitment, trust and work behavior. The case of contingent workers. Personnel Review. 2003, 32(2): 588-604.

[27] de WITTE, H., NÄSWALL, K. Objective versus subjective job insecurity: consequences of temporary work for job satisfaction and organizational commitment in four European countries. Economic and Industrial Democracy. 2003, 24(2): 149-188.

[28] CHAMBEL, M.J., CASTANHEIRA, F. Different temporary work status: Different behaviors in organization. Journal of Business and Psychology. 2006 , 20(3): 351-367.

[29] COYLE-SHAPIRO, J.A.-M., KESSLER,I. Reciprocity through the lens of the psychological contract: Employee and employer perspectives. European Journal of Work and Organizational Psychology. 2002, 11(1): 1-18.

[30] ENGELLANDT, A., RIPHAHN, R.T. Temporary contracts and employee efforts. Labour Economics. 2005, 12(3): 281-299.

[31] MEYER, A., WALLETTE, M. Absence of absenteeism and overtime work: signaling factors of temporary workers? Working Papers. Department of Economics, Lund University, 2005.

[32] SVERKE, M., HELLGREN, J., NÄSWALL, K. No security: A meta-analysis and review of job insecurity and its consequences. Journal of Occupational Health Psychology. 2002, 7: 242-264.

[33] ŻOŁNIERCZYK-ZREDA, D. Psychospołeczne warunki pracy a zaburzenia depresyjne wśród pracujących Polaków. Raport z2. etapu realizacji projektu w ramach $\vee$ etapu programu wieloletniego „Poprawa bezpieczeństwai warunków pracy", finansowanego w latach 2020-2022 w zakresie badań naukowych i prac rozwojowych ze środków Narodowego Centrum Badań. Warszawa: CIOP-PIB, 2021.

Opracowano i wydano na podstawie wyników V etapu programu wieloletniego "Poprawa bez pieczeństwa i warunków pracy", finansowanego w zakresie badań naukowych i prac rozwojowych ze środków Narodowego Centrum Badań i Roz woju (projekt nr I.PB.03 pt. "Psychospołeczne warunki pracy a zaburzenia depresyjne wśród pracujacych Polaków"). Koordynator programu: Centralny Instytut Ochrony Pracy - Państwowy Instytut Badawczy. 